\title{
Characterization of Ethanol Extract from Agarwood (Aquilaria microcarpa
} Baill.) Leaf

Authors

Affiliation

\author{
Beny Rahmanto ${ }^{1 *}$, Wawan Halwany ${ }^{1}$, Fajar Lestari ${ }^{1}$, Khoerul Anwar ${ }^{2}$, Liling Triyasmono ${ }^{2}$, \\ Muhammad Ikhwan Rizki ${ }^{2}$, Maman Turjaman ${ }^{3}$ \\ ${ }^{1}$ Environtment and Forestry Research and Development Institute of Banjarbaru, South \\ Kalimantan, Indonesia \\ ${ }^{2}$ Department of Pharmacy, Faculty of Mathematic and Natural Sciences, Universitas Lambung \\ Mangkurat, South Kalimantan, Indonesia \\ ${ }^{3}$ Forest Research and Development Center, Bogor, West Java, Indonesia
}

\section{ABSTRACT}

The aim of this research is to determine the specific and non-specific parameter from ethanolic extract of A. microcarpa. Specific parameters such as the organoleptic properties, content of water and ethanol soluble compound, and chhromatogram profile of the extract. In contrast, the non-specific parameter includes drying losses, ash levels, microbiological contamination levels, and heavy metal contamination levels. The results showed that the organoleptic properties of ethanolic extract of $A$. microcarpa was thick, blackish brown color, bitter taste and have distinctive odor. The average content of water-soluble compounds of $66.93 \%$, ethanol-soluble of $47.97 \%$, and chromatogram profile with $\mathrm{Rf} 0.636$. The non-specific parameters results were drying losses of $5.50 \%$, total ash content of $3.73 \%$, acid-insoluble ash of $2.13 \%$, microbial contamination testing results of $1.2 \times 102-5.5 \times 103$ colonies $/ g$, and total mold/ yeast contaminants of 10-100 colonies/g. Heavy metal contamination $\mathrm{Pb}$ levels and $\mathrm{Cd}$ levels were $5.47 \mathrm{mg} / \mathrm{kg}$ and $0.19 \mathrm{mg} / \mathrm{kg}$ respectively. These studies suggested that the observed specific and non-specific parameters may be helpful for establishing pharmacopoeia standards of A. microcarpa and to ensure uniformity of extract effect.

\section{INTRODUCTION}

Agarwood is one of non-timber forest products (NTFPs) which has high economic value. Agarwood-producing plants are widely known as members of the Thymelaeaceae family, Aquilaria and Gyrinops genus. They can grow in the temperature range of $24-32^{\circ}$ C, humidity of $80-90 \%$, with rainfall of 1,000-1,500 mm/year (Jensen and Meilby 2008). The land condition for growing of agarwood producing trees are mostly classified as podsolic soil with sandy clay or marginal land with altitude of 10-400 m a.s.l. One type of them have been widely known cultivated by agarwood producers is Aquilaria microcarpa (Paoli et al. 2001).

Agarwood has many benefits such as anti-asthmatic, stomach pain medication, hepatitis, and cirrhosis (Saidu et al. 2014; Fatmawati and Hidayat 2016). Ethanol extract
* Corresponding author Beny Rahmanto

Jl. A. Yani Km 28,7 Banjarbaru, Kalimantan Selatan, Indonesia 7072

ben_rahmanto@yahoo.com

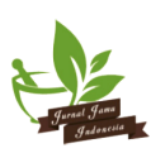


of agarwood leaf has reported contains flavonoids, alkaloids, terpenoids, and glycosides of secondary metabolite compounds (Khalil et al. 2013). Aquilaria microcarpa leaf empirically used by the Tamiyang Layang community in Central Kalimantan for diabetes treatment. Antihyperglycemic activity of agarwood leaf most likely to be associated with increasing of glucose uptake mechanism (Pranakhon et al. 2011; Manoka et al. 2016)

The content of active compounds and the quality of extracts from medicinal plants cannot be guaranteed to always be in constant amounts. Variations in the content of active compounds in the extract products can be due to the following aspects: genetic (seed), environment (place to grow, climate), agronomic (fertilizer, treatment during growth), harvest (time and post-harvest) (Salminen et al. 2001; Osadebe and Ukwueze 2004; Feng et al. 2014). Therefore, the standardization process of extracts is necessary to produce good quality extracts before they are produced on an industrial scale. Standardization of raw materials of medicines from natural ingredients such as medicinal plant extracts is a set of parameters, procedures and methods of measurement whose results are elements related to the pharmaceutical quality paradigm. Standardization is necessary to ensure the efficacy quality uniformity and safety of $A$. microcarpa leaf extract (Jeong et al. 2016). Standardized raw materials and controlled process, they will produce quality products (MoH RI 1995).

The agarwood (Aquilaria microcarpa Baill.) leaf empirically used to reduce blood glucose levels. Previous research has shown an extremely strong antioxidant activity in its ethanolic extract. This study aims to standardize ethanol extracts of $A$. microcarpa leaf based on specific and non-specific parameters. Specific parameters include organoleptic properties, the average content of water-soluble and ethanolsoluble compounds, and chromatogram profile using TLC technique. Meanwhile, non-specific parameters observed were drying losses, total ash content, acidinsoluble ash, microbial contamination, total mold/ yeast contaminants, and heavy metal contamination $(\mathrm{Pb}$ and $\mathrm{Cd})$.

\section{METHODS}

\section{Chemicals and Reagents}

Potato Dextrose Agar, Nutrient Agar, acetic acid, sulfuric acid, ethanol, Folin-Ciocalteau's reagent,
$\mathrm{NaOH}$, and silica gel $60 \mathrm{~F}_{254}$ plate were obtained from $\mathrm{E}$. Merck, Darmstadt, Germany. Pb acetate and Liebermann-Burchard reagent were purchased from Sigma-Aldrich. The other chemical used were analytical grade.

\section{Preparation of Ethanolic Extract}

Aquilaria microcarpa leaves were collected from Barabai, South Kalimantan in November 2016. Authentication of the plant was conducted in Biology Laboratory, Faculty of Mathematic and Sciences, Lambung Mangkurat University. Dry powder of $A$. microcarpa leaf (500 g) was macerated using ethanol $70 \%$ in the macerator with ratio of $1: 10$ for 24 hours while stirring occasionally. Filtrate was separated by filter paper. The residual was remacerated 2 times. All the obtained filtrate was collected and evaporated by rotary evaporator to obtain $1 / 10$ parts, followed by evaporation in water bath until obtained thick extract (Wigati et al. 2017).

\section{Determination of Specific Parameters \\ Organoleptic properties of extracts}

The organoleptic parameters of ethanolic extract of A. microcarpa leaf are determined using the five senses in describing the shape, color, smell, and taste.

\section{Water-soluble compound}

The powdered leaves of 5 grams saturated for 24 hours using $100 \mathrm{~mL}$ water-chloroform (40: 1) in the maceration vessel. The liquid extract obtained is then filtered. The $20 \mathrm{~mL}$ filtrate was evaporated to dry in a shallow, flat-bottomed bowl that had previously been tied. The remainder of the sample was heated at a temperature of $105^{\circ} \mathrm{C}$ to a fixed weight (MoH RI 1995).

\section{Ethanol-soluble compound}

Dry powdered leaves of 5 grams macerated for 24 hours using $100 \mathrm{~mL}$ ethanol. The liquid extract obtained is filtered. The $20 \mathrm{~mL}$ filtrate was evaporated to dry in a shallow, flat-bottomed bowl that had previously been tied. The remainder of the sample was heated at $105^{\circ} \mathrm{C}$ until fixed weight (MoH RI 1995).

\section{Phytochemical contents}

Determination of phytochemical contents conducted by color reaction (tube) test for detected alkaloids, saponins, phenolics, tannins, flavonoids, steroids, terpenoids, and diterpenes contents. 
Chromatogram (TLC) profile

TLC profile analysis was used silica gel F254 as stationary phase and mobile phase used chloroform: methanol (9:1) (MoH RI 2009). Otimization of mobile phase have conducted with several solvent.

\section{Determination Of Specific Parameters Drying losses}

Extract (1 gram) in porcelain cruces heated at $105^{\circ}$ $C$ for 30 minutes and weighed. The extract is flattened to form a thin layer and dried to a fixed weight. The fixed weights obtained were recorded to calculate the percentage of drying shrinkage (MoH RI 2000).

\section{Total ash content}

Determination of ash content is done by weighing 3 grams of ethanolic extract of $A$. microcarpa leaf, placed on asbestos, flattened and heated until ash. Then the ash was weighed (MoH RI 1995).

\section{Acid-insoluble ash}

The ash obtained dissolved $25 \mathrm{~mL}$ chloride acid $10 \%$ $\mathrm{v} / \mathrm{v}$ for $5 \mathrm{~min}$ in porcelain cup then boiled. The obtained solution is filtered using a filter paper. The rest of the ash on filter paper is then washed with hot water. Filter paper and residual ash were heated until the weight is fixed (MoH 1995).

\section{Total bacterial contaminants}

Extract from $10^{-4}$ dilution pippetted with $1 \mathrm{~mL}$ sterile pipette, implanted in Nutriene Agar medium. then incubated at $37{ }^{\circ} \mathrm{C}$ for 24 hours. The number of colonies that grow then observed and counted and multiplied by dilution factor ( $\mathrm{MoH} 2000)$.

\section{Total mold contaminants}

Extract from $10^{-4}$ dilution pippetted with $1 \mathrm{~mL}$ sterile pipette, implanted in Potato Dextrose Agar medium, then incubated at $25{ }^{\circ} \mathrm{C}$ for 3 days. The number of colonies that grow then observed and counted and multiplied by dilution factor ( $\mathrm{MoH} 2000$ ).

\section{Metal contaminants ( $P b$ and $C d$ ) using ICP-OES}

One gram of extract was deconstructed with $\mathrm{HNO}_{3}$ and then fed into a $100 \mathrm{~mL}$ measuring flask and aquadest is added to the boundary marker. Standar solution made with $1 ; 2 ; 3 ; 4$; and 5 ppm series consentration. Serial samples and series solutions were analyzed by ICP-OES. The metal content in the extract was shown in units of $\mathrm{mg} / \mathrm{kg}$ ( $\mathrm{MoH} 2000)$.

\section{RESULT AND DISCUSSION}

\section{Specific Parameters}

Organoleptic properties

Organoleptic test of ethanol extract of $A$. microcarpa leaf was aimed for initial identification of extract by describing shape, color, smell and taste directly with senses (MoH RI 2000). A. microcarpa leaf ethanol extract was thick extract with blackish brown color, distinctive odor and bitter taste. The thick extract was obtained by the separation process and the solvent had evaporated completely. The compound content of the extract gave distinctive odor. Bitter taste was caused by secondary metabolite compounds containing by the extract. (Harborne 2006). Most flavonoids have a bitter or astringent taste or a bitter taste with sweet aftertaste (Hounsome et al. 2008).

\section{Determination of Extract Compound}

Determination of extract compound is aimed to estimate roughly the amount of polar (water-soluble) compounds and the semi-polar or non-polar (solubleethanol) compounds (Saifudin et al. 2011). Determination of this parameter was carried out gravimetrically used two solvents, i.e. water and ethanol solvents. Water is a polar solvent that will dissolve polar compound. Ethanol has the ability to dissolve with a wide polarity ranging from non-polar compounds to polar compounds (Arifin et al. 2006). The level of active compounds in an extract is influenced by age of the plant, time of harvest, climate and place of growth. The results showed that the content of ethanolic extract of $A$. microcarpa leaf in aqueous solution was $66.93 \%$ and ethanol solution was $47.97 \%$. These results simply indicate that the active compound in the $A$. microcarpa leaf was easily extracted by both of these solvents (Devaraj et al. 2010). So the extraction process will be most favorable using polar solvent. Ethanol $70 \%$ is used as a solvent on extraction because of its polarity and solubility of the extract.

\section{Phytochemical content}

Phytochemical screening was aimed to provide an overview of the constituent compounds in the extract (Kristanti et al. 2008). The result showed that the extract compounds contained saponins, phenolics,

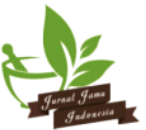


tannins, and flavonoids (Table 1). Saponins were glycosides form of sapogenin, so it will be polar. It was surface-active compounds and can cause foam if shaken in water, because it has micelles form, so the polar group faces out while the non-polar group faces inwards. This condition caused foam formed (Kristanti et al. 2008; Simaremare 2014). Phenolics were widespread in higher plants especially on leaf. Phenol testing was performed with the $\mathrm{FeCl}_{3}$ which was characterized by blackish green or dark blue color after $\mathrm{FeCl}_{3}$ was added. This condition caused by the $\mathrm{Fe}^{3+}$ complex formed (Sa'adah 2010). The tannins test use a gelatinous solution resulting in a precipitate showing the presence of a complex bond between tannins and proteins. The characteristic of tannin is bitter taste especially on the leaf. Flavonoids had diverse types and present in free form (aglycones) or bonded as glycosides. The polymethoxy aglycone was non-polar, the polyhydroxy aglycone was semi-polar, while flavonoid glycosides was polar because it contains hydroxyl and sugar groups (Harborne 2006). Therefore, the flavonoid group can be extracted by universal ethanol solvent. Flavonoids and phenolic have antioxidant effect by capture and neutralize free radicals (Anwar et al. 2017).

Table 1. The phytochemical content test results of ethanolic extract of $A$. microcarpa

\begin{tabular}{clc}
\hline No & \multicolumn{1}{c}{ Test } & Result \\
\hline 1. & Alkaloids & - \\
2. & Saponins & + \\
3. & Phenolics & + \\
4. & Tannins & + \\
5. & Flavonoids & + \\
6. & Steroids & - \\
7. & Terpenoids & - \\
8. & Diterpenes & - \\
\hline
\end{tabular}

\section{Chromatogram Profile}

TLC profile analysis was used silica gel F254 as stationary phase and mobile phase used chloroform: methanol (9:1). The spraying reagent used $10 \% \mathrm{H}_{2} \mathrm{SO}_{4}$. The sulphuric acid ability as reducer agent can damage the chromophore group of the active compound, the wavelength shifted towards longer wavelength and spot will be seen more clearly (Gandjar \& Rohman 2008). This Rf value can be used as a marker or to indicate the counterfeit compound on quantitative and qualitative examination. Based on TLC result (Fig 1) obtained $\mathrm{Rf}$ value was $0.109,0.709$, and 0.909 . It showed the compounds tended to be semi-polar. The polar stationary phase with non-polar mobile phase interacted with the compounds contained in the extract. If the spot was seen in the lower position with small $\mathrm{Rf}$ value, the compounds tended to had similar the stationary phase. This study shows that Rf value in the middle ang higher position, so the dominant compound in the extract was semipolar and polar, which leads to flavonoid or phenolic compounds.

\section{Non-specific Parameters}

The non-specific parameter included drying losses, total ash content, acid insoluble ash contents, bacterial and mold contamination, and metal contamination (Table 2). Drying losses is aimed to provide a maximum range about the compounds lost in the drying process. The drying losses parameter measured residual substance after drying at $105^{\circ} \mathrm{C}$ to constant weight, as percent value ( $\mathrm{MoH} \mathrm{RI} 2000)$. The results showed that A. microcarpa leaf extract drying was $5.50 \%$. The shrinkage rate of drying simplicia based on the raw material drug requirement maximum of $10 \%$ (NADFC RI 2014). Sample drying and extract evaporation process by the non-optimal solvent would leave water residue in the resulting thick extract and it can be bacterial and fungus growth medium. The storage of thick extract in

Table 2. Non-specific parameter results of ethanolic extract of $A$. microcarpa

\begin{tabular}{clc}
\hline No. & \multicolumn{1}{c}{ Parameters } & Result \\
\hline 1. & Drying losses & $5.50 \%$ \\
2. & Total ash content & $3.73 \%$ \\
3. & Acid-insoluble ash & $2.13 \%$ \\
4. & Total bacterial contamination & $1.2 \times 10^{2}-5.5 \times 10^{3}$ colonies $/ \mathrm{g}$ \\
5. & Total mold contamination & $10-100$ colony $/ \mathrm{g}$ \\
6. & Pb contamination & $5.47 \mathrm{mg} / \mathrm{kg}$ \\
7. & Cd contamination & $0.19 \mathrm{mg} / \mathrm{kg}$ \\
\hline
\end{tabular}




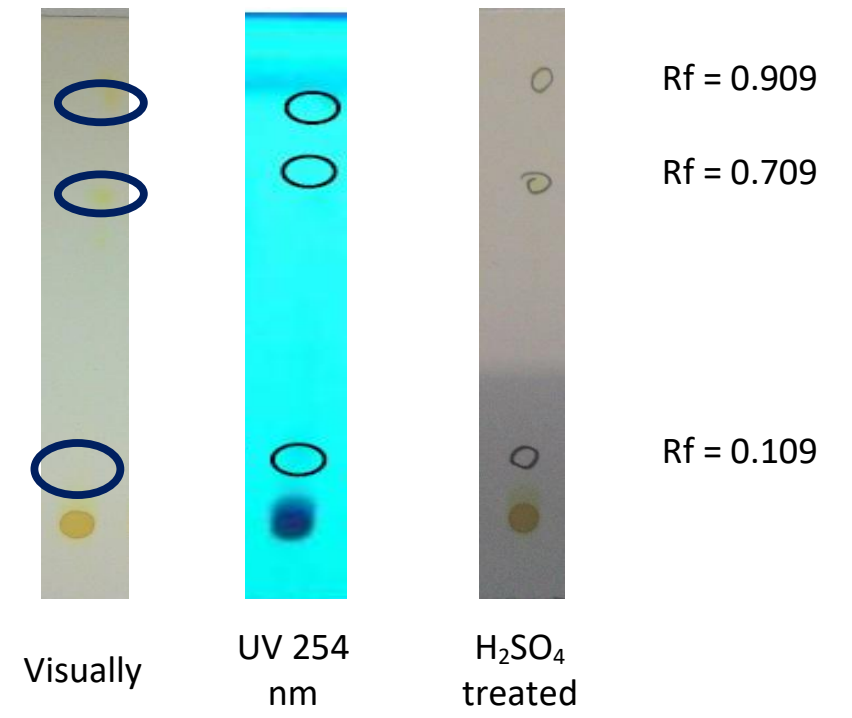

Figure 1. TLC profile analysis of ethanolic extract of $A$. microcarpa. Stationary phase Silica Gel F254, mobile phase chloroform: methanol 9:1

moist places would cause the absorbed water to the extract (Saifudin et al. 2011). Other affecting factors to water content was biological factors such as species, growth area and plant part used for making extract and chemical factors such as extraction method, equiptments, extracted material dryness, and solvent used in the extraction process (MoH RI 2000).

Inorganic material contained in the extract can be determine by total ash content. Ash is inorganic residual of combustion from an organic material. The ash content depends on material and spying manner. Determination of ash content extract was conducted to determine whether or not processing to extract is good, know the material used type, and as parameter value before being used as food or pharmaceutical preparation. Ash content should have small value because this parameter indicates the presence of heavy metal contaminant that is resistant to high temperature. The total ash content of ethanolic extract of $A$. microcarpa leaf was $3.73 \%$. According to Herbal Pharmacopoeia Indonesia, the requirement of extract total ash content maximum at value of $13.3 \%$ (MoH RI 2009).

Determination of acid-insoluble ash content was aimed to evaluate the extract on contamination of silicate-containing materials, such as soil and sand. The hydrochloric acid solvent was used to dissolve the organic metals, while the acid-insoluble usually contain silicates. The acid-isoluble ash content of $A$. microcarpa leaf ethanol extract was $2.13 \%$. This showed the acidinsoluble ash content obtained on $A$. microcarpa leaf ethanol extract fulfilled the standard. The acid soluble ash content is not more than $2.6 \%$ according to $\mathrm{FHI}$ requirement ( $\mathrm{MoH} \mathrm{RI} 2009$ ). This indicates that the acid soluble ash content obtained on ethanol extract of $A$. microcarpa leaves meets the standard.

Total bacteria and mold test of $A$. microcarpa leaf ethanol extract were conducted to calculate microbe contaminating the extract. This test included the determination of the number of microorganism and to indicate the presence or absence of certain bacteria in the extract. Excessive microbe can alter organoleptic characteristics and nutritional or nutritional status changes in the extract (NADFC RI 2008). The maximum limit of microbes or bacterial in food is $1.0 \times 10^{4}$ colonies/g and maximum limit of molds is $1.0 \times 10^{3}$ colonies/g. Total bacteria and mold test on $A$. microcarpa leaf ethanol extract was $1.2 \times 10^{2}-5.5 \times 10^{3}$ colonies/g and 10-100 colonies/g respectively.

The determination of heavy metal contamination was conducted to ensure that the extract didn't contained heavy metals exceeding limits that can be toxic to the body. Based on the study results, ethanol extract of $A$. microcarpa leaf contained $\mathrm{Pb}$ of 5.47 $\mathrm{mg} / \mathrm{kg}$ extract. This level was in accordance with the required maximum limit of $<10.00 \mathrm{mg} / \mathrm{kg}$ (NADFC RI 2014). The Cd content obtained of $0.19 \mathrm{mg} / \mathrm{kg}$, and fulfilled the required maximum limit of $<0.3 \mathrm{mg} / \mathrm{kg}$ (NADFC RI 2014). High levels of metal in the soil caused by fertilizers, pesticides, industrial or household waste and mining (Charlena 2004). The impact of high $\mathrm{Pb}$ concentration to the body results in poisoning symptoms such as acute gastrointestinal irritation, vomiting, abdominal pain, and diarrhea. $\mathrm{Pb}$ affect the intelligent nervous system and growth, so it can cause brain damage, convulsion, behavioral disorders, and death. The impact of high Cd concentration to the body in the long term can accumulate the kidney and liver. $\mathrm{Cd}$ can cause abnormal uric acid calcium and phosphorus in urine. It can also cause lung respiration damage, bone fragility, and affect the reproductive system (Widaningrum et al. 2007).

With the manufacture of standardized extracts, it is expected to produce extracts that meet the requirements of NADFC RI. The results of this study will be useful to complete information related to the

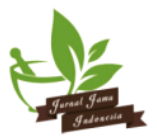


identification and standardization of ethanol extract quality of A.microcarpa leaf.

\section{CONCLUSION}

From this study, it can be concluded that the specific parameter testing result shows ethanolic extract of $A$. microcarpa leaf takes the form of thick extract with blackish brown color, distinctive odor and bitter taste, water-soluble content of $66.93 \%$ and ethanol $47.97 \%$, phytochemical contents of saponins, phenolics, flavonoids, and tannins, with TLC profile shows some spots on Rf 0.636. Non-specific parameter testing results shows drying losses of $5.5 \%$, total ash content of $3.73 \%$, acid-insoluble ash content of $2.13 \%$, bacterial contamination of $1.2 \times 10^{2}-5.5 \times 10^{3}$ colonies $/ \mathrm{g}$, mold contamination of $10-100$ colonies/g, Pb levels of 5.47 $\mathrm{mg} / \mathrm{kg}$, and $\mathrm{Cd}$ levels of $0.19 \mathrm{mg} / \mathrm{kg}$.

\section{DAFTAR PUSTAKA}

Andrunganyan, RR. 2015. Aktivitas Ekstrak Etanol Daun Gaharu (Aquilaria microcarpa Baill.) Terhadap Tes Toleransi Glukosa Oral, Glikogen Hati Dan Histopatologi Pankreas Tikus Putih Yang Diinduksi Aloksan [skripsi]. Banjarbaru (ID): Fakultas Matematika dan IImu Pengetahuan Alam, Universitas Lambung Mangkurat.

Anwar K, Wigati D, Sudarsono, Nugroho AE. 2017. Blood glucose reduction of combination of Andrographis paniculata (Burm.f) Ness and Morinda citrifolia L. ethanolic extract in neonatal streptozotocin-induced Type 2 diabetes mellitus rats. International Food Research Journal. 24(5): 2153-2160.

Arifin H, Anggraini N, Handayani D, Rasyid R. 2006. Standardization of Eugenia cumini Merr leaf ethanol extract. Jurnal Sains dan Teknologi Farmasi. 11(2):88-93.

Charlena. 2004. Pencemaran Logam Berat Timbal (Pb) dan Cadmium (Cd) pada Sayur-sayuran [disertasi]. Bogor (ID): Program Pascasarjana, Universitas Pertanian Bogor.

Devaraj S, Ismail S, Ramanathan S, Marimuthu S, Fei MY. 2010. Evaluation of the hepatoprotective activity of standardized ethanolic extract of Curcuma xanthorrhiza Roxb. Journal of Medicinal Plant Research. 4(23):2512-2517.

Fatmawati, Hidayat R. 2016. Anti cancer of Aquilaria malaccensis leaves on human cervical cancer cells.
European Journal of Pharmaceutical and Medical Research. 3(1):46-49.

Farzaei MH, Khanavi M, Moghaddam G, Dolatshahi F, Rahimi R, Shams-Ardekani MR, Amin G, Hajimahmoodi M. 2014. Standardization of Tragopogon graminifolius DC. extract based on phenolic compounds and antioxidant activity. Journal of Chemistry. 2014:1-5.

Feng S, Luo Z, Zhang Y, Zhong Z, Lu B. 2014. Phytochemical contents and antioxidant capacities of different parts of two sugarcane (Saccharum officinarum L.) cultivars. Food chemistry. 51:452458.

Gandjar IG, Rohman A. 2008. Kimia Farmasi Analisis. Yogyakarta (ID): Pustaka Pelajar.

Harbone JB. 2006. Metode fitokimia: penuntun cara modern menganalisis tumbuhan. ITB (ID): Bandung.

Hounsome N1, Hounsome B, Tomos D, Edwards-Jones G. 2008. Plant metabolites and nutritional quality of vegetables. Journal of Food Science. 73(4):R4865.

Jensen A, Meilby H. 2008. Returns from harvesting a commercial non-timber forest product and particular characteristics of harvesters and their strategies: Aquilaria crassna and agarwood in Lao PDR. Economic Botany. 64(1):34-45.

Jeong KY, Son M, Choi SY, Park KH, Park HJ, Hong CS, Lee JH, Park JW. 2016. Standardization of weed pollen extracts, Japanese hop and mugwort, in Korea. Yonsei Medical Journal. 57(2):399-406.

Khalil AS, Rahim AA, Taha KK, Abdallah KB. 2013. Characterization of methanolic extracts of agarwood leaves. Journal of Applied Pharmaceutical Science1(3): 78-88.

Kristanti AV, Aminah NS, Tanjung M, Kurniadi B. 2008. Buku teks fitokimia. Surabaya (ID): Airlangga University Press.

Manoka S, Sungthong B, Sato H, Sugiyama E, Sato VH. 2016. Hypoglycemic and antioxidant activities of the water extract of Aquilaria crassna leaves in streptozotocin-nicotinamide-induced type-2 diabetic mice. Natural Product Communications. 11(6):757-761.

Ministry of Health of the Republic of Indonesia. 1995. Materia Medika Indonesia Jilid VI. Jakarta (ID): Ministry of Health of the Republic of Indonesia.

Ministry of Health of the Republic of Indonesia. 2000. Standard parameters of medicinal extracts of 
medicinal plants. Jakarta (ID): Ministry of Health of the Republic of Indonesia.

Ministry of Health of the Republic of Indonesia. 2009. Herbal Pharmacopoeia of Indonesia. Edisi I. Jakarta (ID): Ministry of Health of the Republic of Indonesia.

National Agency of Drug and Food Control of Republic of Indonesia. 2008. Pengujian mikrobiologi pangan. Jakarta (ID): Center for Drug and Food Testing of National Agency of Drug and Food Control of Republic of Indonesia.

National Agency of Drug and Food Control of Republic of Indonesia. 2014. Regulation of the Head of National Agency of Drug and Food Control of Republic of Indonesia Number 12 Year 2014 about Traditional Medicinal Quality Requirements.

Osadebe PO, Ukwueze SE. 2004. A comparative study of the phytochemical and anti-microbial properties of the Eastern Nigerian specie of African Mistletoe (Loranthus micranthus) sourced from different host trees. Bio-research. 2(1):18-23.

Paoli GD, Peart DR, Leighton M, Samsoedin I. 2001. An ecological and economic assessment of the nontimber forest product gaharu wood in Gunung Palung National Park, West Kalimantan, Indonesia. Conservation Biology. 15(6):1721-1732.

Pranakhon R, Pannangpetch P, Aromdee C. 2011. Antihyperglycemic activity of agarwood leaf extracts in STZ-induced diabetic rats and glucose uptake enhancement activity in rat adipocytes. Songklanakarin Journal of Science \& Technology. 33(4):405-410.

Ratnani RD, Hartati I, Anas Y, Endah DP, Khilyati DDD. 2015. Specific and non-specific standardization of andrographolid hydrotropi extraction from sambiloto (Andrographis paniculata). Proceedings of the National Seminar on Opportunities of Herbs as Alternative Medicine Year 2015. Faculty of Pharmacy Wahid Hasyim University, Semarang.

Rawar EA, Rohman A. 2016. Validation of atomic absorption spectrophotometry and mercury analyzer for analysis of cadmium, lead and mercury in red chili pepper. Asian Journal of Agricultural Research. 10:65-71.

Sa'adah, L. 2010. Isolation and identification of tanin compound from belimbing wuluh leaves (Averrhoa bilimbi L.) [thesis]. Malang (ID): Faculty of Science and Technology, Islamic State University (UIN) Maulana Malik Ibrahim.

Saidu AN, Abubakar AN, Daniel MU, and Kabiru AY. 2014. Phytochemical screening and effect of methanolic extract of Azadirachta indica leaf in alloxan induced diabetic rats. IOSR-JPBS. 9(1): 1620.

Saifudin A, Rahayu V, and Teruna HY. 2011. Natural Medicinal Materials Standardization. First Edition. Graha IImu. Yogyakarta.

Salminen JP, Ossipov V, Haukioja E, and Pihlaja K. 2001. Seasonal variation in the content of hydrolysable tannins in leaves of Betula pubescens. Phytochemistry. 57(1): 15-22.

Simaremare ES. 2014. Phytochemical screening of leaf extracts of daun gatal (Laportea decumana (Roxb.) Wedd). Pharmacy. 11: 98-107.

Sulistijowati A, and Gunawan D. 1998. The effect of kembang bulan (Tithonia diversifolia A. Gray) leaf extract to Candida albicans and its chromatography profile. Media of Health Research \& Development, 8:32-37.

Tiwari P, Kumar B, Kaur M, Kaur G, and Kaur H. 2011. Phytochemical screening and extraction: A review. Internationale Pharmaceutica Sciencia, 1: 98-106.

Widaningrum, Miskiyah, and Suismono. 2007. Heavy metal contamination in vegetables and alternatives to prevention of contaminants. Bulletin of Agricultural Postharvest Technology. 3: 17-27.

Wigati, D, Anwar K, Sudarsono, and Nugroho AE. 2017. Hypotensive activity of ethanolic extracts of Morinda citrifolia L. leaves and fruit in dexamethasone-induced hypertensive rat. Journal of Evidence-Based Integrative Medicine. 22(1): 107113. 